\title{
Microbial Biomass - Carbon (SMB-C) and Dehydrogenase Activity (DHA) in Wetland Rice Ecosystem
}

\author{
Prabha Susan Philip $^{1 *}$, R.K. Kaleeswari ${ }^{2}$ and K. Kumar ${ }^{3}$ \\ ${ }^{1}$ ICAR - National Bureau of Soil Survey and Land Use Planning, Regional Centre, \\ Delhi-110012, India \\ ${ }^{2}$ Department of Soil Science, ${ }^{3}$ Department of Agricultural Microbiology, Tamil Nadu \\ Agricultural University, Tamil Nadu, India \\ *Corresponding author
}

\section{Keywords}

Soil microbial biomass carbon, Dehydrogenase activity, INM

Article Info

Accepted:

04 August 2018

Available Online:

10 September 2018

\section{A B S T R A C T}

A field experiment was conducted in clay loam of Wetlands of TNAU farm, Coimbatore to study the impact of nutrient management technologies on Soil Microbial Biomass-Carbon (SMB-C) and Dehydrogenase Activity (DHA) of soil under lowland rice ecosystem. In the present investigation, integration of inorganics, Sesbania aculeata and biofertilizers have intensively triggered the microbial activities, which would have resulted in higher dehydrogenase activity. The better nutrient management leads to better crop productivity which results in incorporation of larger organic matter through root biomass or leaf fall, root exudates, etc. thereby influencing the $\mathrm{C}$ dynamics in soil. The nutrient level and moisture play a dominant positive role towards the dehydrogenase activity. The dehydrogenase activity and biomass carbon content tended to increase with the advancement in crop growth. The results from the correlation analysis have revealed that the soil nutrient status has a direct and significant role in enhancing the soil microbial and enzyme activities. Integrated use of inorganic fertilizers, Sesbania aculeata and Azolla orchestrates soil nutrient availability, biomass production, biochemical activities and favorable soil physical environment that facilitate effective carbon sequestration in lowland rice ecosystem.

\section{Introduction}

Microbial activity in a soil drives organic matter decomposition and mineralization processes, leading to release of organically bound plant nutrients in forms available to growing plants (Izaurralde and Cerre, 2002). Soil organisms produce extracellular enzyme and hyphae which hold soil particles and create aggregates. Soil microbial biomass is the active component in soil organic matter. The change in the microbial biomass carbon reflects the process of microorganism propagation and degradation utilizing soil carbon.

It is the centre of majority of biological activity in soil and therefore, the knowledge of the microbial biomass carbon is highly essential. 
Lenhard (1956) introduced the concept of determining the metabolic activity of microorganisms in soil and other habitats by measuring dehydrogenase activity. Soil microbial biomass is more sensitive to agricultural management than other fractions. Therefore, the short-term effect of soil management on soil properties can be determined by looking at the soil microbial biomass (Haynes, 1993). The activity of dehydrogenase is significantly correlated with soil biomass in organic amended soil (Garcia Gill et al., 2000).

It plays a significant role in the biological oxidation of soil organic matter by transferring protons and electrons from substrates to acceptors (Glinski et al., 1986). Soil microbial biomass increased with root growth and rooting density of the crop. Addition of root exudates would be least in soil under fallow rotations and greatest under forage, which is consistent with biomass results. The better nutrient management leads to better crop productivity which results in incorporation of larger organic matter through root biomass or leaf fall, root exudates, etc. thereby influencing the $\mathrm{C}$ dynamics in soil ${ }^{6}$ (Lynch and Panting, 1980).

Rice occupies a pivotal place in Indian Agriculture, as it is the staple food for more than 70 per cent of our population and a source of livelihood for about 120 to 150 million rural households. In India rice spreads over an area of about 43.9 million hectares that accounts for 26.91 per cent of the world's paddy rice area with total production of 93.88 tonnes. In Tamil Nadu rice cultivation spreads over an area of 2.10 million hectares with a total production of 9.3 million tonnes (Policy note, 2015). The supply of nutrients in the form of organic manures helps in sustaining favorable soil physical properties thereby enhancing the water and nutrient use efficiencies.
Green manuring is the cheapest locally available resource for building up soil fertility and supplementing plant nutrients, especially $\mathrm{N}$. Green manure is an organic resource offer the twin benefits of soil quality and fertility enhancement while meeting a part of nutrient needs of crops (Vinod Kumar et al., 1999). The higher reduction in $\mathrm{pH}$, electrical conductivity and exchangeable sodium percentage of soil was observed by using organic manures along with chemical fertilizers as compared to fertilizers alone (Yadav and Kumar, 2002). Chelating action of organic compounds released during decomposition of organic sources increased the availability of micronutrients by preventing their fixation, oxidation, precipitation and leaching (Yadav and Kumar, 2000). Incorporation of Sesbania aculeata residue in soil, fixed more atmospheric $\mathrm{N}$ biologically in the soil and also added higher amount of organic matter which is a good indicator of soil fertility and improved status of available nutrients in the soil (Dwivedi et al., 2005).

Roychowdhry et al., (1979) reported that Azolla, applied as a dead organic matter, provides only nitrogen to the crop on mineralization and does not help in improving the status of soil aggregation. Singh (1980) revealed that the cumulative release of phosphorus was found to be superior in fresh Azolla incorporation than fresh blue green algae. Blue green algae which colonize in the rice fields have been reported to be responsible for the long term fertility of paddy fields. The presence of algal symbiont Anabaena Azollae in its leaf cavities helps in $\mathrm{N}$ fixation and in turn increases soil organic content in terms of total $\mathrm{N}$ after death of the Azolla plant (Watanabe et al., 1977). On an average BGA contributes $25-30 \mathrm{~kg}$ nitrogen per hectare per season and leads to 10-15 per cent increase in rice productivity (Rao and Burns, 1991). 


\section{Materials and Methods}

A field experiment was conducted in clay loam Vertic Ustochrept at Field No. B4 of Wetlands of TNAU farm, Coimbatore $\left(11^{\circ} 12^{\prime}\right.$ $\mathrm{N}$ and $77^{\circ} 03^{\prime} \mathrm{E}$ ) during 2012 with rice (var. $\mathrm{CO}(\mathrm{R}) 50$ ), a medium duration rice variety (130-135 days). The experiment was laid out in Randomized Block Design (RBD) with three replications. The plot size was $20 \mathrm{~m}^{2}$ (5 $\mathrm{m} \times 4 \mathrm{~m}$ ). Initial soil characteristics of the experimental site were: $\mathrm{pH}$ 8.18; electrical conductivity $0.42 \mathrm{dS} \mathrm{m}^{-1}$ and cation exchange capacity $19.5 \mathrm{cmol}\left(\mathrm{p}^{+}\right) \mathrm{kg}^{-1}$, organic carbon $0.63 \%$, available $\mathrm{N}\left(216 \mathrm{~kg} \mathrm{ha}^{-1}\right)$, available $\mathrm{P}$ $\left(20.4 \mathrm{~kg} \mathrm{ha}^{-1}\right)$ and available $\mathrm{K}\left(533 \mathrm{~kg} \mathrm{ha}^{-1}\right)$ status.

The DTPA extractable available Fe, $\mathrm{Zn}, \mathrm{Mn}$ and $\mathrm{Cu}$ were $12.59,6.00,11.39$ and $4.00 \mathrm{mg}$ $\mathrm{kg}^{-1}$ respectively. The treatments consisted of $\mathrm{T}_{1}$ - Untreated control; $\mathrm{T}_{2}-75 \% \mathrm{RDF}$ (112.50:37.50:37.50 kg N, $\mathrm{P}_{2} \mathrm{O}_{5}, \mathrm{~K}_{2} \mathrm{O}+25 \mathrm{~kg}$ $\mathrm{ZnSO}_{4}$ ha $\left.^{-1}\right) ; \mathrm{T}_{3}-\mathrm{T}_{2}+$ Sesbania aculeata @6.25t ha ${ }^{-1} ; \mathrm{T}_{4}-\mathrm{T}_{3}+$ Azolla@ @ $500 \mathrm{~kg} \mathrm{ha}^{-1}$; $\mathrm{T}_{5}-\mathrm{T}_{3}+\mathrm{BGA} @ 10 \mathrm{~kg} \mathrm{ha}^{-1} ; \mathrm{T}_{6}-100 \% \mathrm{RDF}$ (150:50:50 kg N, $\mathrm{P}_{2} \mathrm{O}_{5}, \mathrm{~K}_{2} \mathrm{O}+25 \mathrm{~kg} \mathrm{ZnSO}_{4}$ $\left.\mathrm{ha}^{-1}\right) ; \mathrm{T}_{7}-\mathrm{T}_{6}+$ Sesbania aculeata @6.25 ha ${ }^{-1}$; $\mathrm{T}_{8}-\mathrm{T}_{6}+$ Azolla@ $500 \mathrm{~kg} \mathrm{ha}{ }^{-1} ; \mathrm{T}_{9}-\mathrm{T}_{6}+$ BGA@10 kg ha ${ }^{-1}$.

The microbial biomass carbon was determined by the incubation and fumigation technique of Jenkinson and Powlson (1976). The dehydrogenase activity was measured by the methodology outlined by ${ }^{8}$ Casida et al., (1964).

\section{Results and Discussion}

Correlation between microbial biomass $\mathrm{C}$ and dehydrogenase activity was positive and highly significant $(\mathrm{r}=0.894 * *)$. Linear increase in dehydrogenase activity was observed with increase in level of inorganic fertilizers. This observation is in agreement with the findings of Dhkar and Mishra (1983) that highlighted the dominant positive role of nutrient level towards the enzyme activities. Incorporation of Sesbania aculeata would have increased the microbial growth and improved the soil-water-plant relationships. Irrespective of the level of chemical fertilizers, combined application of organic manures and biofertilizers significantly enhanced the biomass carbon.

The dehydrogenase activity was found to be significantly increased by nutrient levels, organic manuring and biofertilizer application. DHA was significantly higher in $100 \% \mathrm{RDF}+$ Sesbania aculeata + Azolla treatment (34.85 $\mu \mathrm{g}$ TPF $\mathrm{g}^{-1}$ soil $24 \mathrm{hr}^{-1}$ ). At harvest stage, application of $100 \%$ RDF + Sesbania aculeata + Azolla significantly enhanced the dehydrogenase activity $\left(44.23 \mu \mathrm{g}\right.$ TPF $\mathrm{g}^{-1}$ soil $24 \mathrm{hr}^{-1}$ ) (Table 1). The increased dehydrogenase activity might be attributed to the incorporation of Sesbania aculeata, owing to increase in microbial activity of the soil. Similar results were reported by Pauscal et al., (1998).

Application of $100 \%$ RDF + Sesbania aculeata + Azolla increased the amount of biomass carbon (435 mg kg-1) (Table 2). The maximum effect of inputs on the microbial biomass was realized under $100 \% \mathrm{RDF}+$ Sesbania aculeata + Azolla. The lowest biomass carbon content of $162 \mathrm{mg} \mathrm{kg}^{-1}$ was recorded in control at harvest stage. The highest biomass carbon content of $597 \mathrm{mg} \mathrm{kg}^{-1}$ was recorded in treatment $100 \% \mathrm{RDF}+$ Sesbania aculeata + Azolla. Gayatri Verma and Mathur (2009) indicated the integrated role of FYM and chemical fertilizers in increasing microbial biomass carbon. Application of Azolla, besides showing primary effects, is also known to fix $\mathrm{C}$ during photosynthesis. Photosynthetic efficiency of Azolla over BGA was also reported by Mie Mie Aung et al., (2002). 
Table.1 Effect of nutrient management strategies on dehydrogenase activity at tillering and harvest stages of rice crop

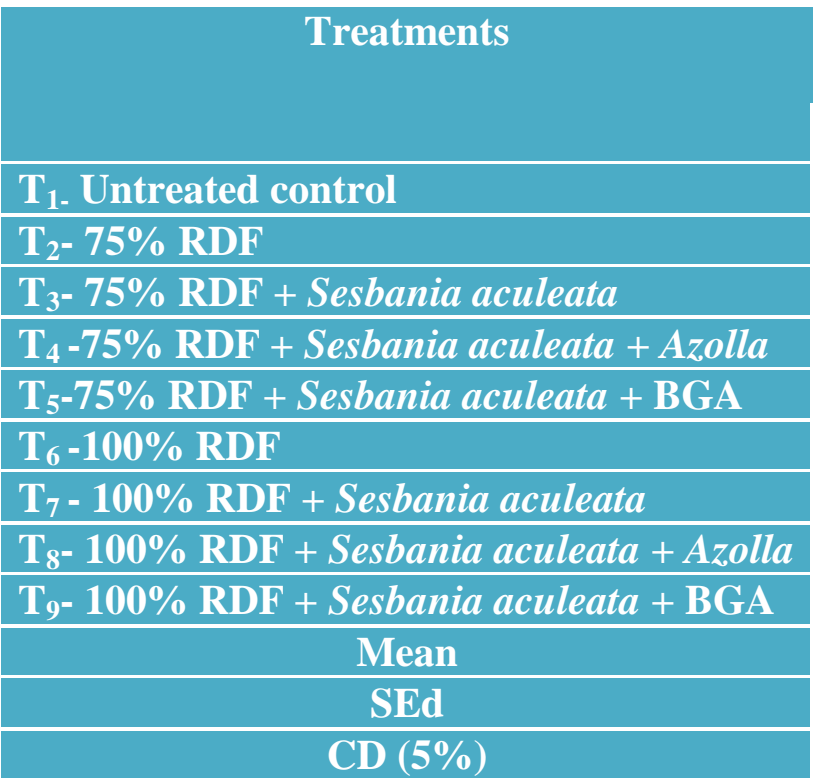

\begin{tabular}{|c|c|}
\hline $\begin{array}{c}\text { Dehydrogenase activity } \\
\left.\text { hillering }^{-1}\right)\end{array}$ & $\begin{array}{c}(\mu \mathrm{g} \text { TPF g } \\
\text { Til soil } 24\end{array}$ \\
\hline 12.75 & 21.61 \\
\hline 14.73 & 23.57 \\
\hline 17.51 & 27.06 \\
\hline 28.46 & 36.08 \\
\hline 20.64 & 30.55 \\
\hline 18.57 & 28.22 \\
\hline 25.67 & 34.67 \\
\hline 34.85 & 44.23 \\
\hline 29.37 & 38.14 \\
\hline 22.36 & 31.56 \\
\hline 0.71 & 1.22 \\
\hline 1.5 & 2.6 \\
\hline
\end{tabular}

Table.2 Effect of nutrient management strategies on soil microbial biomass carbon at tillering and harvest stages of rice crop

\begin{tabular}{|c|}
\hline Treatments \\
\hline $\mathrm{T}_{1-}$ Untreated control \\
\hline $\mathrm{T}_{2-} \mathbf{7 5 \%} \mathrm{RDF}$ \\
\hline $\mathrm{T}_{3}-75 \% \mathrm{RDF}+$ Sesbania aculeata \\
\hline $\mathrm{T}_{4}-75 \%$ RDF + Sesbania aculeata + Azolla \\
\hline $\mathrm{T}_{5}-75 \%$ RDF + Sesbania aculeata + BGA \\
\hline $\mathrm{T}_{6}-100 \% \mathrm{RDF}$ \\
\hline $\mathrm{T}_{7}-100 \%$ RDF + Sesbania aculeata \\
\hline $\mathrm{T}_{8^{-}} \mathbf{1 0 0 \%}$ RDF + Sesbania aculeata + Azolla \\
\hline $\mathrm{T}_{9-} \mathbf{1 0 0} \%$ RDF + Sesbania aculeata + BGA \\
\hline Mean \\
\hline SEd \\
\hline $\mathrm{CD}(\mathrm{P}=\mathbf{0 . 0 5})$ \\
\hline
\end{tabular}

\begin{tabular}{|c|c|}
\hline \multicolumn{2}{|c|}{ Biomass carbon $\left(\mathrm{mg} \mathrm{kg}^{-1}\right)$} \\
\hline Tillering & Harvest \\
\hline 90 & 162 \\
\hline 135 & 217 \\
\hline 190 & 262 \\
\hline 310 & 400 \\
\hline 254 & 326 \\
\hline 174 & 318 \\
\hline 260 & 404 \\
\hline 435 & 597 \\
\hline 387 & 513 \\
\hline 248 & 355 \\
\hline 10.58 & 9.39 \\
\hline 22.43 & 19.90 \\
\hline
\end{tabular}

Correlation coefficients between soil microbial biomass carbon (S-MBC) and dehydrogenase activity (DHA)

\begin{tabular}{|c|c|}
\hline & DHA \\
\hline SMIBC & $0.894^{* *}$ \\
\hline
\end{tabular}

${ }^{* *}$ Correlation significant at $P=0.01 ;{ }^{*}$ Correlation significant at $P=0.05$ 
Incorporation of Sesbania aculeata in combination with RDF and with RDF + Azolla or BGA increased the microbial biomass carbon compared to that of inorganic fertilizers alone. These observations are in accordance with the findings of Haiyan Chu et al., (2007), Khosro Mohammadi (2011) and Neetu Pareek and Yadav (2011).

The soil microbial biomass acts as the transformation agent of the organic matter in the soil. As such, the biomass is both a source and sink of the carbon, nitrogen and phosphorus contained in organic matter. Generally, soil microbial biomass is more dynamic fraction of soil organic $C$. Dehydrogenase activity is only present in viable cells; it is thought to reflect the total range of oxidative activity of soil microflora and consequently may be considered to be a good indicator of microbial activity. The nutrient level and moisture play a dominant positive role towards the dehydrogenase activity. In the present investigation, integration of inorganics, Sesbania aculeata and biofertilizers have intensively triggered the microbial activities, which would have resulted in higher dehydrogenase activity. Buildup of microbial biomass would be mainly due to the microbial biomass contained in the organic residues and the addition of substrate carbon, which stimulates the indigenous soil micro-biota. Moreover, the supply of additional mineralizable and readily hydrolysable $\mathrm{C}$ due to the incorporation of Sesbania aculeata resulted in higher microbial activity and thereby microbial biomass carbon. The dehydrogenase activity and biomass carbon content tended to increase with the advancement in crop growth. This might be due to the increased root and shoot biomass production at later stages of crop growth. The results from the correlation analysis have revealed that the soil nutrient status has a direct and significant role in enhancing the soil microbial and enzyme activities. Integrated use of inorganic fertilizers, Sesbania aculeata and Azolla orchestrates soil nutrient availability, biomass production, biochemical activities and favorable soil physical environment that facilitate effective carbon sequestration in lowland rice ecosystem.

\section{Acknowledgements}

This research work was carried out during 'Masters Degree Programme'. The first author is thankful to Indian Council of Agricultural Research (ICAR) for the grant of junior research fellowship during the entire course of research. The authors are thankful to Tamil Nadu Agricultural University for the all facilities and amenties provided during the course of work.

\section{References}

Casida, L. E. Jr., D.A. Klein and T. Santoro. (1964). Soil dehydrogenase activity. Soil Science, 98: 371-376.

Dhkar, M.S. and R.R. Mishra. 1983. Dehydrogenase and urease activities of maize (Zea mays L.) field soils. Plant and Soil, 70: 327-333.

Garcia-Ruiz, R., V. Ochoa., M. Bales Hinojosa and J.A. Carrcira. (2008). Suitability of enzyme activity for the monitoring of soil quality improvement in organic agricultural system. Soil Biology and. Biochemistry, 40: 21372145.

Gayatri Verma and A.K. Mathur. (2009). Effect of integrated nutrient management on active pools of soil organic matter under maize-wheat system of a Typic Haplustalf. Journal of Indian Society Soil Science, 57(3): 317322.

Glinski, J., Z. Stepniewska, and M. Brzezinska. (1986). Characterization of 
the dehydrogenase and catalase activity of the soils of two natural sites with respect to the soil oxygenation status. Polish Journal of Soil Science, 19:4752.

Haiyan Chu, Xiangui Lin, Takeshi fujii, Sho Morimoto, Kazuyuki Yagi, Junli $\mathrm{Hu}$, Jiabao Zhang. (2007). Soil microbial biomass, dehydrogenase activity, bacterial community structure in response to long term fertilizer management. Soil Biology and Biochemistry, 39: 2971-2976.

Haynes, R.J. (1993). Effect of sample pretreatment on aggregate stability measured by wet sieving or turbidimetry on soils of different cropping history. Journal of Indian Society Soil Science, 44: 261-270.

https://foodprocessingindia.co.in/state_pdf/Ta milNadu/Policy_note_agriculture_201516.pdf

Izaurralde, R. C. and C.C. Cerri. (2002).Organic matter management. In: Encyclopedia of Soil Science (ed. Lal, R.), Marcel Dekker, New York, pp. 910-916.

Jenkinson, D.S. and D.S. Powlson (1976). The effects of biocidal treatments on metabiolism in soil - A method for measuring soil biomass. Soil Biology and Biochemistry, 8: 209-213.
Khosro Mohammadi. (2011). Soil microbial activity and biomass as influenced by tillage and fertilization in wheat production. American- Eurasian Journal of Agriculture and Environmental Science, 10(3): 330-337.

Lenhard, G. (1956). The dehydrogenase activity in soil as a measure of the activity of soil microorganisms. $Z$. Pflancenernaehr. Dueng. Bodenkd. 73: $1-11$.

Lynch, J.M. and L.M. Panting. 1980. Cultivation and the soil biomass. Soil Biology and Biochemistry, 12: 29-33.

Mie Mie Aung, Ulrich Eberhardt, L.G.P. Vlek. (2002). International Conference on challenges to organic farming and sustainable land use in the tropics and sub tropics held at University of Kansas - Witzenhausen.

Neetu Pareek and B.L. Yadav. (2011). Effect of organic manures on soil physico chemical properties, soil microbial biomass and yield of mustard under irrigation of different residual sodium carbonate waters. Journal of Indian Society Soil Science, 59(4): 336-342.

Pauscal, J.A., T. Hernandez, C. Garcia and M. Ayuso. (1998). Enzymatic activities in an arid soil amended with urban organic wastes. Laboratory experiments. Bioresource Technology, 64: 131-138.

\section{How to cite this article:}

Prabha Susan Philip, R.K. Kaleeswari and Kumar, K. 2018. Microbial Biomass - Carbon (SMB-C) and Dehydrogenase Activity (DHA) in Wetland Rice Ecosystem. Int.J.Curr.Microbiol.App.Sci. 7(09): 384-389. doi: https://doi.org/10.20546/ijcmas.2018.709.047 